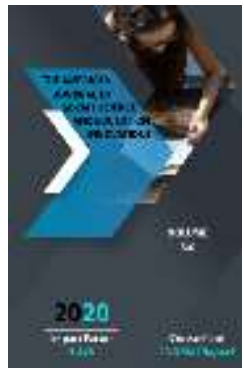

Journal Website: http://usajournalshub.c om/index,php/tajssei

Copyright: Original content from this work may be used under the terms of the creative commons attributes 4.0 licence.

\section{National and Universal Content of Fine Arts. Ancient History and Development of Fine Arts of Uzbekistan}

\author{
Shuhrat Nazarovich Mamatkulov \\ Lecturer, Termez State University, Uzbekistan \\ Kholida Ibragimova \\ Student, Termez State University, Uzbekistan
}

\title{
ABSTRACT
}

This article provides information about the national and universal content of fine arts, the ancient history and development of fine arts in Uzbekistan. Before we can study the fine arts, we should, first, look at the history and development stages of it. The fine arts originated in ancient times as a result of the development of the labor process. The main factors in the development of the fine arts, as well as the difficulties in the development of the content of primitive art and the stages of development to the present day are given.

\section{KEYWORDS}

Fine Arts, Primitive Art, Central Asian Art, Nationalism, Memorials, Painters and Sculptors, Perfection.

\section{INTRODUCTION}

It Independence gave our country not only political freedom, but also the freedom to live as a nation, the freedom to think independently. Due to this, we had the opportunity to study the field of art, its history from the point of view of secularism and humanity.
As our first president said, "We have been inherited not only monuments and relics from the past, but also the intellect, intellect and wisdom of our ancestors, the ability to think, the rich spiritual world." It is no exaggeration to say that it is the duty of every child of this country to preserve this sacred heritage as the 
apple of our eye and pass it on to the next generation.

On the basis of the words of the President of the Republic of Uzbekistan Sh.M.Mirziyoev: "We consider it our priority to improve the activities of all links of the education system in accordance with modern requirements." The idea of creating a system of education, paying more attention to radically improving the effectiveness of education and preparing young people for independent living. The role of art, especially fine arts, is of great importance for the further development of education in our country. The fine arts play an important role in enriching people's imaginations and shaping their aesthetic tastes.

\section{METHODOLOGY}

Before we can study the fine arts, we must first look at the history of the visual arts. Fine arts originated in ancient times as a result of the development of the labor process. In the process of work, human thinking has developed, the sense of beauty has increased, and the concepts of beauty, convenience and usefulness in reality have expanded. With the advent of class society, however, great changes took place in social development; mental labor began to separate from physical labor. This played an important role in the development of science and art.

Professional art and artists emerged during this period. Art, on the other hand, has become a powerful ideological tool for propagating the ideology of the ruling class, demonstrating its uniqueness and class. Nevertheless, the talented artists who grew up among the masses created works that expressed the aspirations of the working people, their notions of beauty and selfishness, nobility and humanity. The life, behavior, customs, successes and failures of the people are reflected in their works. Such art, which has existed in every age, depicts the beauties of life, instills in people high qualities and virtues, encourages them to strive for equality, freedom, brotherhood, and a bright future. Indeed, the cultural values created by humanity are not just ordinary riches, but also a reflection of the human mind, its reflection on life. To teach the history of world art, to understand the laws of its development, to get acquainted with rare monuments, to study the feelings and life experiences of people of the past means to know the formation of ideological and aesthetic views. Undoubtedly, it will help people to enrich their life experiences and take a broader and more comprehensive approach to life.

The territory of Uzbekistan has been inhabited since the time of primitive society. Rock paintings at the locations where they lived, a variety of bronze jewelry, labor and weapons of war help to know the life of a primitive community man. Although the picture is a bit simplistic, it depicts the lives of primitive people and the time they hunted wild animals. Through the depiction of wild boars running around, horned bulls, and people hiding under the guise of masks, the primitive community artist was able to masterfully capture the intense movement and excitement of this hunting scene. In the photo, the image of animals in particular is expressive. Their strength and agility are vitally interpreted. Archaeologists from Uzbekistan, including Boysun and Termez districts, Samarkand, Tashkent, Jizzakh, Khorezm and Fergana districts, have found many paintings on the walls. The nigatics of these pictures are very limited. Mostly depicting images of animals or hunting scenes. Pets are also depicted. These images play an important role in the 
subjugation of people living in a sedentary society in the primitive social order, in the understanding that their thinking is evolving.

\section{RESULTS AND DISCUSSION}

There was a strong interest in art in Central Asia during the period of slavery. The house of the rich, the walls of the temple are decorated with paintings, patterns. Monuments found in Khorezm, especially animal and mural paintings from the Soil Fortress (III-IV centuries) serve as important evidence for the study of ancient Uzbek art.

The VI-VIII centuries were a period of rise in the history of folk art and culture. Many large monuments and luxury buildings have been built during these centuries. The ruins of the palaces in Varakhsha (Bukhara province), Afrosiyob (Samarkand province) and the sculptures on which the paintings were painted on their walls are still astonishing. One of the most effective Russian artists in Uzbekistan was Pavel Petrovich Benkov. He made a great contribution to the development of Uzbek ex-Soviet art and the development of national cadres. During his first years in Uzbekistan, he worked on many canvases dedicated to Bukhara, Khiva and Samarkand. These are mainly in the semi-landscape and semi-domestic genres, in which the artist masterfully depicts the daily life of the people against the backdrop of ancient rare architecture. Beginning in the 1930s, Benkov began to pay more attention to reality. The changes taking place in the lives of women find their artistic expression in her works. The painting "Friends" (1940) is a major work of P. Benkov on the theme of friendship. In this play, the artist sings of friendship between peoples through the image of an Uzbek and a Russian girl watching the grapes drowned in the ishkam. The work makes a good impression on the viewer with its rich color, naturalness in the movement of images.

The war years were a big test for Uzbek artists. They were ideologically hardened. Artists and sculptors tried to create works that could be an incentive for frontline victory. Moscow, Leningrad, Kiev, Kharkiv art institutes, which were evacuated to Uzbekistan during the war years, and the accompanying leading artists D. Moor, V. Favorsky and others revived the artistic life of the republic. Uzbek artists were encouraged to create ideological and artistic works. It ended with the universal victory of the people over German fascism. The years of peaceful construction began.

He set to work to rebuild the cities and villages destroyed in the war, and to increase agricultural production. Peoples, artists who have always dedicated their work to the party, and have tried to reflect these changes in their lives on their bright canvases. Since that time, Uzbek art has entered a new stage in its development. The main direction of Uzbek Soviet art has been the creation of complete, ideologically high, artistically harmonious works. Human beauty, the splendor of nature began to find expression in the canvas of our artists. "The portrait A. Hidoyatov" (1949), "The portrait of Oybek: (1949) by A. Abdullayev; "Meeting the Hero" (1947) by L. Abdullayev, "Morning at HPP Kayrakkum" (1957) by U. Tansikbayev; "Thoughts of a Mother" R. Akhmedov (1958); "Samarkand" by R. Timurov (1958), "Portrait of a Group of Literary and Artistic Figures of Uzbekistan" by Y. Elizarov (1959), "Golden Autumn" by N. Karakhan (1958); “The Guardian Woman" (1958) by V. Fadeyev; "In the Barn” M.Saidov's (1958); and Ch.Akhmarov's murals and others have taken their rightful place in the history of Uzbek art. They took an active part in all- 
Union exhibitions and demonstrated the growing influence of our art. In particular, the All-Union Art Exhibition in Moscow in 1957 and the art exhibitions organized in 1959 during the Decade were important events in the history of Uzbek fine arts. Our artists have created ideologically and artistically harmonious works on modern themes, delighting the fans of fine arts. During these years, remarkable achievements were also made in the field of sculpture. Examples are the portraits of F. Grishchenko, the statues of $\mathrm{H}$. Husniddinkhodjaev, the bas-relief of $\mathrm{A}$. Kramskaya and the works of P. Ivanova depicting animals.

\section{CONCLUSION}

From the 6os and 70s, Uzbek art entered a new phase. During this period, not only in the works of older artists, but also in the works of young people, the search for new means of expression, the emphasis on its emotional side in the interpretation of the work has become more pronounced. Interpreting reality in an uplifting spirit, paying special attention to the expressive potential of lines, striving to increase the sensitivity of color, defines an important aspect of the research of artists of these years. This can be seen in the paintings of B. Boboev and R. Choriev, in the cartoons of T. Mukhamedov. Uzbek art has come a long way. It has been serving for the bright future of humanity as an integral part of multinational art.

\section{REFERENCES}

1. Mirziyoyev, S. M. (2016). Together We Will Build a Free and Prosperous Democratic State of Uzbekistan. Uzbekistan.

2. Mirziyoyev, S. M. (2016, December 7). The Rule of Law and the Protection of Human Interests are the Key to the Development of the Country and the Well-Being of the People [Lecture].

3. Hasanov, R. (2006). Practical Lessons on the Methods of Teaching Fine Arts. Tashkent.

4. Karimov, I. A. (1997). A Harmoniously Developed Generation is the Foundation of Uzbekistan's Development [Lecture].

5. Khodjamkulov, U. N., Makhmudov, K. S., \& Shofkorov, A. M. (2020). The Issue of Spiritual and Patriotic Education of Young Generation in the Scientific, Political and Literary Heritage of Central Asian Thinkers. International Journal of Psychosocial Rehabilitation, 24(05), 66946701. 